\title{
Article \\ Effects of Nitrogen Additions on Soil Respiration in an Asian Tropical Montane Rainforest
}

\author{
Fangtao $\mathrm{Wu}^{1,2}$, Changhui Peng ${ }^{1,2,3, * \mathbb{D}}$, Weiguo Liu ${ }^{1,2}$, Zhihao Liu ${ }^{1,2}$, Hui Wang ${ }^{1,2}$, Dexiang Chen ${ }^{4}$ and Yide Li ${ }^{4}$ \\ 1 Center for Ecological Forecasting and Global Change, College of Forestry, Northwest A\&F University, \\ Yangling 712100, China; fangtaowu@nwafu.edu.cn (F.W.); liuweiguo110@nwafu.edu.cn (W.L.); \\ zhihaoliu@nwafu.edu.cn (Z.L.); wanghui@nwafu.edu.cn (H.W.) \\ 2 State Key Laboratory of Soil Erosion and Dryland Farming on the Loess Plateau, Northwest A\&F University, \\ Yangling 712100, China \\ 3 Department of Biology Sciences, Institute of Environment Sciences, University of Quebec at Montreal, \\ C.P. 8888, Succ. Centre-Ville, Montreal, QC H3C 3P8, Canada \\ 4 Jianfengling National Key Field Observation and Research Station for Forest Ecosystem, Research Institute of \\ Tropical Forestry, Chinese Academy of Forestry, Guangzhou 510520, China; dexiangchen@ritf.ac.cn (D.C.); \\ lyd@ritf.ac.cn (Y.L.) \\ * Correspondence: peng.changhui@uqam.ca
}

check for updates

Citation: Wu, F.; Peng, C.; Liu, W.; Liu, Z.; Wang, H.; Chen, D.; Li, Y. Effects of Nitrogen Additions on Soil Respiration in an Asian Tropical Montane Rainforest. Forests 2021, 12, 802. https://doi.org/10.3390/ f12060802

Academic Editor: Choonsig Kim

Received: 3 May 2021

Accepted: 15 June 2021

Published: 18 June 2021

Publisher's Note: MDPI stays neutral with regard to jurisdictional claims in published maps and institutional affiliations.

Copyright: (c) 2021 by the authors. Licensee MDPI, Basel, Switzerland. This article is an open access article distributed under the terms and conditions of the Creative Commons Attribution (CC BY) license (https:/ / creativecommons.org/licenses/by/ $4.0 /)$.

\begin{abstract}
Understanding the impacts of nitrogen $(\mathrm{N})$ addition on soil respiration $\left(R_{\mathrm{S}}\right)$ and its temperature sensitivity $\left(Q_{10}\right)$ in tropical forests is very important for the global carbon cycle in a changing environment. Here, we investigated how $R_{\mathrm{S}}$ respond to $\mathrm{N}$ addition in a tropical montane rainforest in Southern China. Four levels of $\mathrm{N}$ treatments $\left(0,25,50\right.$, and $100 \mathrm{~kg} \mathrm{~N} \mathrm{ha}^{-1} \mathrm{a}^{-1}$ as control (CK), low N (N25), moderate N (N50), and high N (N100), respectively) were established in September 2010. Based on a static chamber-gas chromatography method, $R_{\mathrm{S}}$ was measured from January 2015 to December 2018. $R_{\mathrm{S}}$ exhibited significant seasonal variability, with low $R_{\mathrm{S}}$ rates appeared in the dry season and high rates appeared in the wet season regardless of treatment. $R_{\mathrm{S}}$ was significantly related to the measured soil temperature and moisture. Our results showed that soil $R_{\mathrm{S}}$ increased after $\mathrm{N}$ additions, the mean annual $R_{\mathrm{S}}$ was $7 \%$ higher in $\mathrm{N} 25$ plots, $8 \%$ higher in N50 plots, and $11 \%$ higher in N100 plots than that in the CK plots. However, the overall impacts of $\mathrm{N}$ additions on $R_{\mathrm{S}}$ were statistically insignificant. For the entire study period, the CK, N25, N50, and N100 treatments yielded $Q_{10}$ values of 2.27, 3.45, 4.11, and 2.94, respectively. $\mathrm{N}$ addition increased the temperature sensitivity $\left(Q_{10}\right)$ of $R_{S}$. Our results suggest that increasing atmospheric $N$ deposition may have a large impact on the stimulation of soil $\mathrm{CO}_{2}$ emissions from tropical rainforests in China.
\end{abstract}

Keywords: nitrogen addition; soil respiration; temperature sensitivity; tropical forest

\section{Introduction}

Greenhouse gas (GHG)-induced climate change is a considerable global environmental issue and a challenge for the sustainable development of the world's social economy. Carbon dioxide $\left(\mathrm{CO}_{2}\right)$ is one of the major GHGs and is the largest contributor to global warming [1]. Compared with pre-industrial levels, the amount of $\mathrm{CO}_{2}$ in the atmosphere has increased by nearly $45 \%$, putting it at a level not seen on Earth for millions of years [2]. Terrestrial ecosystems are major regulators of carbon (C) accumulation in the atmosphere [3], with a capacity to store almost three times that of the atmosphere [4]. An improved understanding of the $\mathrm{CO}_{2}$ sinks and sources from major terrestrial ecosystems is essential for quantifying the responses of global $\mathrm{C}$ cycles to both current and future climate change.

Soil respiration, hereafter $R_{\mathrm{S}}$, is one of the largest fluxes in the global C cycle, with a global release of $94.3 \pm 17.9 \mathrm{Pg} \mathrm{Ca}^{-1}$ [5]. Understanding the controls on $R_{\mathrm{S}}$ is essential as even minute variations in $R_{\mathrm{S}}$ may dramatically affect atmospheric $\mathrm{CO}_{2}$ concentrations [6]. Since forests cover about $30 \%$ of the Earth's terrestrial area, respiration from forest soils is widely considered to be a substantial source of atmospheric $\mathrm{CO}_{2}$ [7]. Many environmental 
and biophysical factors could affect respiration from forest soils through direct or indirect effects on autotrophic respiration and heterotrophic respiration, including climate conditions, management practices, soil properties, and nutrient availability, all of which have different impacts for different forest types [8-11].

$\mathrm{N}$ has long been considered the most important limiting nutrient for plant production and respiration in land ecosystems [12]. $\mathrm{N}$ deposition has been shown to significantly affect $R_{\mathrm{S}}[13,14]$, but the direction of the measured effects is inconsistent. Previous research has reported that $\mathrm{N}$ deposition suppressed [6,7], stimulated [15,16], or had no effect $[17,18]$ on $R_{S}$. These contradicting findings regarding the responses of $R_{\mathrm{S}}$ to $\mathrm{N}$ deposition are probably caused by different $\mathrm{N}$ deposition forms and levels [19] and the initial soil $\mathrm{N}$ status [20]. Thus, detailed research is required to understand the impact of $\mathrm{N}$ deposition on $R_{\mathrm{S}}$ and its control mechanism.

$\mathrm{N}$ deposition has been projected to be enhanced in China in the next few decades [21] owing to increased human activity. To better comprehend the impact of elevated $\mathrm{N}$ deposition on forest $R_{\mathrm{S}}$, there have been several simulated $\mathrm{N}$ deposition experiments conducted in different forest types across China. For example, Du et al. [22] conducted an $\mathrm{N}$ addition experiment in a temperate forest, which indicated that different types of $\mathrm{N}$ addition have different impacts on $R_{S}$; this finding was consistent with Wang et al. [19]. In a cold temperate forest, Liu et al. [23] observed that low level $\mathrm{N}$ treatments significantly promoted $R_{\mathrm{S}}$ in the growing season, the opposite of the impact seen with high level $\mathrm{N}$ treatments. In subtropical forests, Deng et al. [24] discovered that the stimulating impact of $\mathrm{N}$ addition on $R_{\mathrm{S}}$ was weakened throughout the study period. Tu et al. [13] demonstrated that $\mathrm{N}$ additions could increase the amount and quality of litterfall, microbial activity, and fine root biomass, all of which were then linked to increased $R_{\mathrm{S}}$. Peng et al. [25] recently reported that $R_{\mathrm{S}}$ decreased with increased $\mathrm{N}$ addition and was related to the amount of litterfall input.

Tropical forests have a vital role in controlling global and regional climate [26] and may display noteworthy responses to increased $\mathrm{N}$ deposition [27]. In addition, tropical forests are more typically nitrogen-rich [28], so their $R_{\mathrm{S}}$ may show different responses to $\mathrm{N}$ deposition compared with other forest types. To date, however, there are very few investigations $[20,27]$ on the effect of $\mathrm{N}$ availability on $R_{\mathrm{S}}$ from tropical forests in China where $\mathrm{N}$ deposition rates are expected to increase with the rapid expansion of agricultural and industrial activities. Hence, additional investigations are necessary to explore the links between $R_{\mathrm{S}}$ and $\mathrm{N}$ availability in tropical forests.

Although several previous studies have investigated $\mathrm{N}$ deposition in tropical montane rainforest ecosystems [26,29], the impacts of $\mathrm{N}$ availability on $R_{\mathrm{S}}$ have not yet been reported in the Jianfengling National Natural Reserve (JFLNNR) in China. Here we performed a field experiment to examine the impacts of $\mathrm{N}$ additions on $R_{\mathrm{S}}$ in the reserve. Our specific objectives were to: (1) clarify the dynamic characteristics of $R_{S}$ and its relationship with relevant environmental factors; and (2) assess the impacts of $\mathrm{N}$ additions on $R_{\mathrm{S}}$ and its temperature sensitivity $\left(Q_{10}\right)$. We hypothesized that $\mathrm{N}$ additions would increase the $R_{S}$ and its $Q_{10}$. We hope to enrich our understanding about the influence of $\mathrm{N}$ addition on $R_{S}$ in tropical rainforests, and to provide basic data for quantification and simulation of $R_{S}$ under global change.

\section{Materials and Methods}

\subsection{Site Description}

The experiment was conducted in an undisturbed tropical montane rainforest within the JFLNNR [30], Hainan Province, China ( $18^{\circ} 43^{\prime} \mathrm{N}, 108^{\circ} 53^{\prime}$ E, $870 \mathrm{~m}$ a.s.l.) [29]. The JFLNNR is categorized as a tropical monsoon climate, with a dry season (November-April) and a wet season (May-October). The mean annual rainfall is approximately $2449 \mathrm{~mm}$, with about $80-90 \%$ occurring in the wet season [31]. The mean annual air temperature is $19.8^{\circ} \mathrm{C}$ [30]. The most common plant species in the study area are members of Lauraceae and Fagaceae [32]. The annual litterfall production ranged from 6.18 to $10.85 \mathrm{t} \mathrm{ha}^{-1} \mathrm{a}^{-1}$, with an average production of $7.69 \mathrm{tha}^{-1} \mathrm{a}^{-1}$ [33]. The soils in the study site are predominantly lateritic yellow soils. Soil texture is sandy clay loam ( $57.1 \%$ sand, $18.2 \%$ silt, $24.7 \%$ clay) [30]. The topography in the study site is relatively homogeneous, with a slope ranging from $0^{\circ}$ 
to $5^{\circ}$ [34]. The $\mathrm{N}$ deposition measured within the JFLNNR is $9.0 \mathrm{~kg} \mathrm{~N} \mathrm{ha}^{-1} \mathrm{a}^{-1}$ [34]. Mean soil $\mathrm{pH}$ and bulk density are 4.1 [30] and $1.1 \mathrm{~g} \mathrm{~cm}^{3}$ [26], respectively. The contents of $C$ and $\mathrm{N}$ in the topsoil at the study site are 35.5 and $1.4 \mathrm{~g} \mathrm{~kg}^{-1}$, respectively [29]. The rainforest has never been disturbed by human activities.

\subsection{Field Manipulations}

The $\mathrm{N}$ deposition simulation experiment started in September 2010 [29]. Four N addition treatments included CK $\left(0 \mathrm{~kg} \mathrm{~N} \mathrm{ha}^{-1} \mathrm{a}^{-1}\right), \mathrm{N} 25\left(25 \mathrm{~kg} \mathrm{~N} \mathrm{ha}^{-1} \mathrm{a}^{-1}\right), \mathrm{N} 50$ $\left(50 \mathrm{~kg} \mathrm{~N} \mathrm{ha}^{-1} \mathrm{a}^{-1}\right)$, and $\mathrm{N} 100\left(100 \mathrm{~kg} \mathrm{~N} \mathrm{ha}{ }^{-1} \mathrm{a}^{-1}\right)[29,34]$. The $\mathrm{N}$ fertilizer $\left(\mathrm{NH}_{4} \mathrm{NO}_{3}\right)$ was diluted in $100 \mathrm{~L}$ of water and sprayed onto each treatment area with a sprayer. Notably, the $\mathrm{CK}$ treatment received the same water $(100 \mathrm{~L})$ without $\mathrm{N}$ additions to maintain similar water conditions between the treatments. A detailed description of the $\mathrm{N}$ treatment at the study area can be obtained in Tang et al. [26] and Zhou [34]. In early January 2015, about 4 years after the start of the $\mathrm{N}$ additions, twelve $10 \times 10 \mathrm{~m}^{2}$ plots were established: three plots each for the CK, N25, N50, and N100 treatments. These plots were separated by buffer strips with a width of more than $10 \mathrm{~m}$. The fertilization rate and method are the same as previously described in Zhou [34].

\subsection{Soil Respiration and Environmental Parameter Measurements}

$R_{\mathrm{S}}$ was observed from January 2015 to December 2018 using the static chamber. The chambers were made of polyvinyl chloride pipe and consisted of two parts: a cylindrical base frame and a removable top (inner diameter $=20 \mathrm{~cm}$ and height $=40 \mathrm{~cm}$ ) [35]. The cylindrical base frames were permanently inserted into the soil $(7 \mathrm{~cm})$ of each plot. Any living plants within the fixed base frame were removed by hand twice a month. When sampling, the removable top was inserted into the base frame. Measurements were taken approximately twice a month. Four gas samples were taken using $10-\mathrm{mL}$ vacuum tubes (Kangiian, Taizhou, China) at 10-min intervals after chamber closure [35]. Simultaneously, the chamber temperature was measured with a mercury thermometer (Shuangbo, Changzhou, China). The concentrations of $\mathrm{CO}_{2}\left(R_{\mathrm{S}}\right)$ in the samples were measured using gas chromatography (Agilent 7890B; Agilent Technologies Inc., Santa Clara, CA, USA). We calculated $R_{\mathrm{S}}$ according to the rate of change in $\mathrm{CO}_{2}$ concentrations over time after chamber closure [36,37].

Soil temperature $\left({ }^{\circ} \mathrm{C}\right)$ at a $5 \mathrm{~cm}$ depth was monitored using digital thermometers (Saiyasi, Dandong, Liaoning, China) outside each chamber during gas collection. The volumetric soil moisture (\%) at a $5 \mathrm{~cm}$ depth was measured with a ML3 ThetaProbe (Delta-T Devices, Cambridge, UK) outside each chamber during the $R_{\mathrm{S}}$ measurement. Air temperature and air pressure were provided by the local weather station at Jianfengling.

\subsection{Soil Characteristics}

Soil samples were collected in June 2016, June 2017, and June 2018 using a soil auger. Three of the samples were taken from 0 to $10 \mathrm{~cm}$ depth in each treatment plot and combined. Subsequently, the large stones, roots, and litter were removed by a sieve (diameter $=2 \mathrm{~mm}$ ). After collection, all soils were kept at $4{ }^{\circ} \mathrm{C}$ before analysis. Soil ammonium $\left(\mathrm{NH}_{4}{ }^{+}-\mathrm{N}\right)$ and nitrate $\left(\mathrm{NO}_{3}{ }^{-}-\mathrm{N}\right)$ were determined by a continuous flow analyzer (SEAL-AA3; Seal Analytical, Norderstedt, Germany); microbial biomass C and N (MBC and MBN) in soil were analyzed using the methods in Badalucco et al. [38].

\subsection{Statistical Analysis}

The widely used exponential regression model [39] was performed to analyze the relationship between the $R_{\mathrm{S}}$ and soil temperature:

$$
R_{\mathrm{S}}=\mathrm{m} \times \mathrm{e}^{\mathrm{nT}}
$$

where $R_{\mathrm{S}}$ represents the soil respiration value; $\mathrm{T}$ is the measured soil temperature; and $\mathrm{m}$ and $\mathrm{n}$ are the model coefficients. 
Temperature sensitivity $\left(Q_{10}\right)$ of $R_{\mathrm{S}}$ was calculated as follows:

$$
Q_{10}=\mathrm{e}^{10 \mathrm{n}}
$$

We used the simple linear regression models to reflect the relationships between $R_{\mathrm{S}}$ and soil environmental factors (soil moisture, $\mathrm{NH}_{4}^{+}-\mathrm{N}, \mathrm{NO}_{3}{ }^{-}-\mathrm{N}, \mathrm{MBC}$, and $\mathrm{MBN}$ ). Repeated measures ANOVA was applied to reveal the impacts of the $\mathrm{N}$ treatment, measurement date, and their interaction on $R_{\mathrm{S}}$. The statistical significance of differences in $R_{\mathrm{S}}$ and the soil environmental factors across the $\mathrm{N}$ addition treatments was examined by one-way ANOVA with an LSD test. All analyses were accomplished using SPSS (version 17.0; SPSS Inc., Chicago, IL, USA), drawing through OriginPro (version 9.1.0; Origin Lab, Northampton, MA, USA) to complete. Statistical significance was evaluated as $p<0.05$.

\section{Results}

\subsection{Soil Environmental Conditions}

During the study period from January 2015 to December 2018, soil temperature and moisture displayed distinct seasonal cycles in all treatments (Figure 1a,b). Generally, soil was dry and cool in the dry season and became wet and warm in the wet season. The soil temperature and moisture measured in the CK plots varied from 11.3 to $24.3^{\circ} \mathrm{C}$ and from $20.0 \%$ to $35.5 \%$, respectively (Figure $1 \mathrm{a}, \mathrm{b}$ ). Over all plots and years, the mean soil temperature was $20.1{ }^{\circ} \mathrm{C}$ and mean soil moisture was $26.4 \%$. No significant variations were detected in the soil temperature and moisture among the N25, N50, N100, and CK treatments during the study period (Table 1). The $\mathrm{NH}_{4}{ }^{+}-\mathrm{N}, \mathrm{NO}_{3}{ }^{-}-\mathrm{N}, \mathrm{MBC}$, and $\mathrm{MBN}$ had no significant variations between the four treatments CK, N25, N50, and N100 (Table 1).

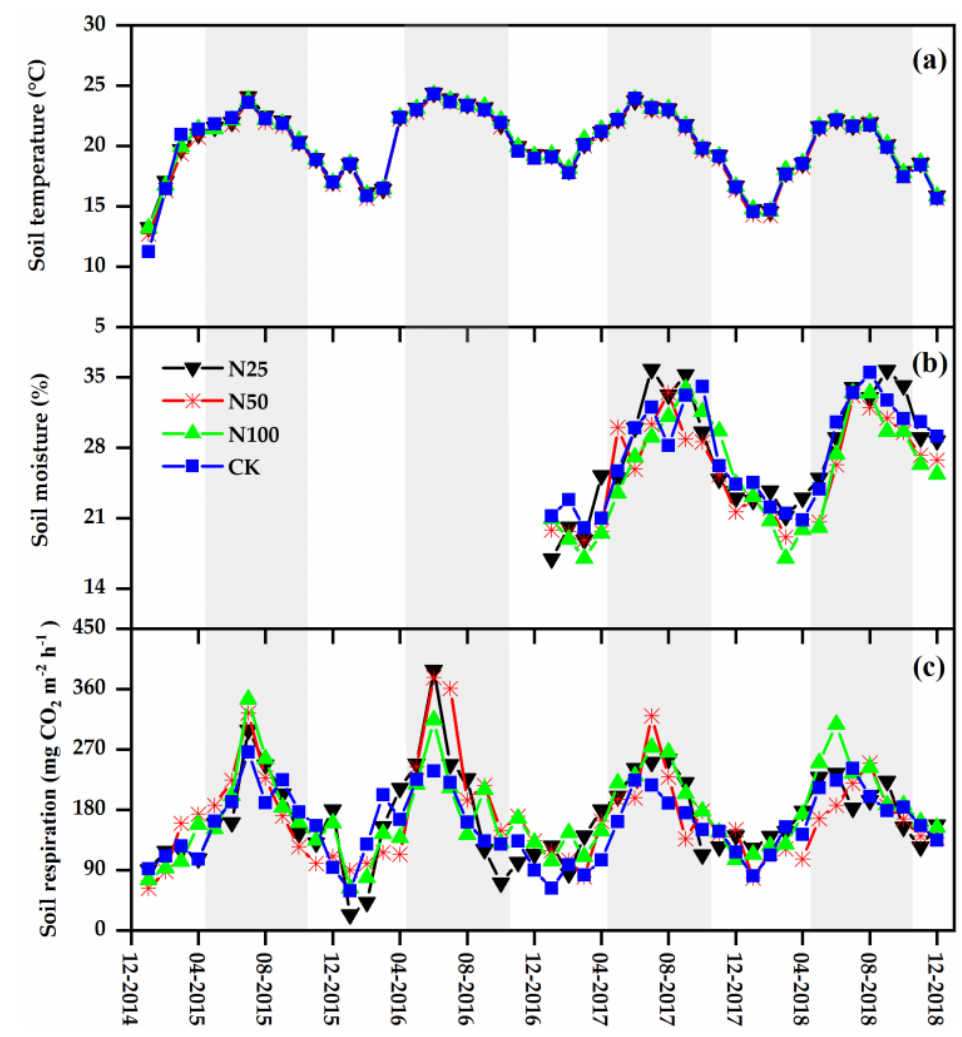

Figure 1. Changes in soil temperature (a), soil moisture $(\mathbf{b})$, and soil respiration $\left(R_{S}\right)(\mathbf{c})$ measured in a tropical montane rainforest within the JFLNNR from January 2015 to December 2018. The shaded areas indicate the wet seasons (May-October). N25, N50, N100, and CK represent 25, 50, 100, and $0 \mathrm{~kg} \mathrm{~N} \mathrm{ha}^{-1} \mathrm{a}^{-1}$ nitrogen (N) addition treatments, respectively. From January 2015 to December 2016, the soil moisture was not observed. 
Table 1. Selected soil characteristics under different $\mathrm{N}$ treatments. $\mathrm{N}$ additions had no significant impacts on any variable shown.

\begin{tabular}{ccccc}
\hline & \multicolumn{3}{c}{ N Treatment } & \\
\cline { 2 - 5 } & N25 & N50 & N100 & CK \\
\hline Soil temperature $\left({ }^{\circ} \mathrm{C}\right)$ & $20.1 \pm 0.4$ & $19.9 \pm 0.4$ & $20.1 \pm 0.4$ & $20.0 \pm 0.4$ \\
Soil moisture $(\%)$ & $27.4 \pm 1.2$ & $25.5 \pm 1.0$ & $25.5 \pm 1.1$ & $27.3 \pm 1.0$ \\
$\mathrm{NH}_{4}{ }^{+}-\mathrm{N}\left(\mathrm{mg} \mathrm{kg}^{-1}\right)$ & $18.9 \pm 2.0$ & $16.1 \pm 1.2$ & $19.0 \pm 2.9$ & $15.5 \pm 1.3$ \\
$\mathrm{NO}_{3}{ }^{-}-\mathrm{N}\left(\mathrm{mg} \mathrm{kg}^{-1}\right)$ & $14.4 \pm 1.8$ & $15.4 \pm 2.4$ & $13.8 \pm 2.8$ & $11.5 \pm 1.0$ \\
$\mathrm{MBC}\left(\mathrm{mg} \mathrm{kg}^{-1}\right)$ & $108.5 \pm 17.0$ & $81.5 \pm 19.6$ & $87.8 \pm 15.9$ & $98.6 \pm 24.5$ \\
$\mathrm{MBN}\left(\mathrm{mg} \mathrm{kg}^{-1}\right)$ & $105.4 \pm 18.2$ & $101.4 \pm 19.3$ & $88.4 \pm 9.4$ & $106.5 \pm 18.8$ \\
\hline
\end{tabular}

$\mathrm{N} 25, \mathrm{~N} 50, \mathrm{~N} 100$, and $\mathrm{CK}$ represent $25,50,100$, and $0 \mathrm{~kg} \mathrm{~N} \mathrm{ha}^{-1} \mathrm{a}^{-1} \mathrm{~N}$ addition treatments, respectively. Data are mean \pm standard error of the mean.

\subsection{Soil Respiration and Its Temperature Sensitivity}

$R_{\mathrm{S}}$ varied significantly across seasons (Table 2), with low values appeared in the dry season and high values appeared in the wet season in all studied $\mathrm{N}$ treatments (Figure 1c). In the CK plots, $R_{\mathrm{S}}$ varied from $59.29 \mathrm{mg} \mathrm{CO}_{2} \mathrm{~m}^{-2} \mathrm{~h}^{-1}$ in the dry season to $266.07 \mathrm{mg}$ $\mathrm{CO}_{2} \mathrm{~m}^{-2} \mathrm{~h}^{-1}$ in the wet season. The seasonal patterns and rates of $R_{\mathrm{S}}$ under the four treatments were similar in 2015, 2016, 2017, and 2018 (Figure 1c). The inter-annual variability (coefficient of variation) of $R_{S}$ in the N25, N50, N100, and CK treatments was $4 \%, 8 \%, 7 \%$, and $6 \%$, respectively. The mean $R_{\mathrm{S}}$ rate during the 4 years was $168.16,168.80,174.38$, and $156.97 \mathrm{mg} \mathrm{CO}_{2} \mathrm{~m}^{-2} \mathrm{~h}^{-1}$ for the N25, N50, N100, and CK treatments, respectively. Compared with CK, the $R_{\mathrm{S}}$ increased by $7 \%, 8 \%$, and $11 \%$ in the N25, N50, and N100 treatments (with an average of $9 \%$ ), respectively. However, from the repeated measures ANOVA results, $N$ treatment and the interaction between $\mathrm{N}$ treatment and measurement date had statistically insignificant effects on $R_{S}(F=1.84, p=0.19$ and $\mathrm{F}=0.72, p=0.70$, respectively; Table 2). Significant variations in $R_{\mathrm{S}}$ between the $\mathrm{CK}$ and $\mathrm{N}$ addition treatments were also not detected for different observation years by one-way ANOVA (Figure 2). Further, there were no significant variations in $R_{\mathrm{S}}$ across treatments in both the dry and wet seasons (Figure 3).

In this rainforest, $R_{\mathrm{S}}$ exhibited significant correlations with soil temperature and moisture (Figure 4; Table 3). $R_{\mathrm{S}}$ increased exponentially with soil temperature in all treatments $(p<0.001$ for all; Figure $4 a$; Table 3$) . R_{S}$ increased linearly with soil moisture in all treatments $(p<0.005$ for all; Figure $4 \mathrm{~b}$; Table 3$)$. Under similar soil moisture conditions, $R_{\mathrm{S}}$ was the higher in $\mathrm{N}$ addition plots and lower in CK plots. The four-year $Q_{10}$ values were $3.45,4.11,2.94$, and 2.27 in the N25, N50, N100, and CK treatments, respectively (Table 3), indicating that $Q_{10}$ has been increased by $52 \%, 81 \%$, and $30 \%$ in the N25, N50, and N100 treatments (with an average of $54 \%$ ), respectively, when compared to CK. The results of correlation analysis demonstrated that $R_{\mathrm{S}}$ was not significantly related to $\mathrm{NH}_{4}{ }^{+}-\mathrm{N}$, $\mathrm{NO}_{3}{ }^{-}-\mathrm{N}, \mathrm{MBC}$, and $\mathrm{MBN}$ (data not shown).

Table 2. Impacts of experimental treatment, month, and their interaction on $R_{\mathrm{S}}$ tested by repeated measure ANOVA (bold numbers denote significant impacts, $p<0.05$ ).

\begin{tabular}{ccc}
\hline Source of Variation & \multicolumn{1}{c}{$\boldsymbol{R}_{\mathbf{S}}$} \\
\hline & $\boldsymbol{F}$ & $\boldsymbol{p}$ \\
\hline Month & 35.44 & $<\mathbf{0 . 0 0 1}$ \\
Treatment & 1.84 & 0.19 \\
Month $\times$ Treatment & 0.72 & 0.70 \\
\hline
\end{tabular}




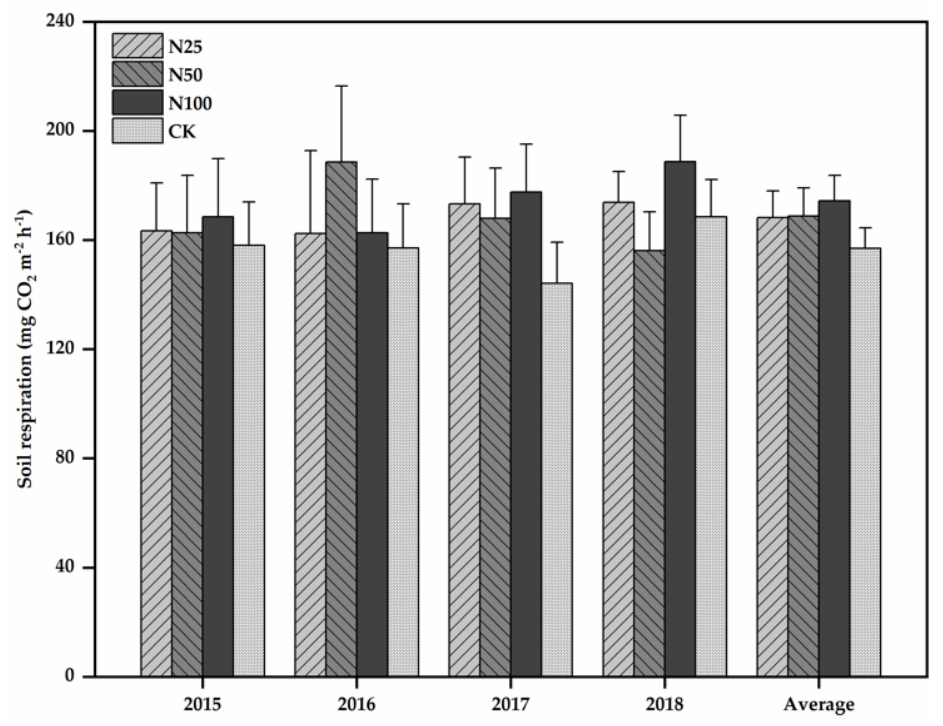

Figure 2. Mean $R_{\mathrm{S}}$ in 2015, 2016, 2017, 2018, and four-year average for each treatment. N25, N50, $\mathrm{N} 100$, and $\mathrm{CK}$ represent 25,50,100, and $0 \mathrm{~kg} \mathrm{~N} \mathrm{ha}^{-1} \mathrm{a}^{-1} \mathrm{~N}$ addition treatments, respectively. Error bars denote the standard errors of the means. No significant variations were found among the four $\mathrm{N}$ treatments across each year by one-way ANOVA.
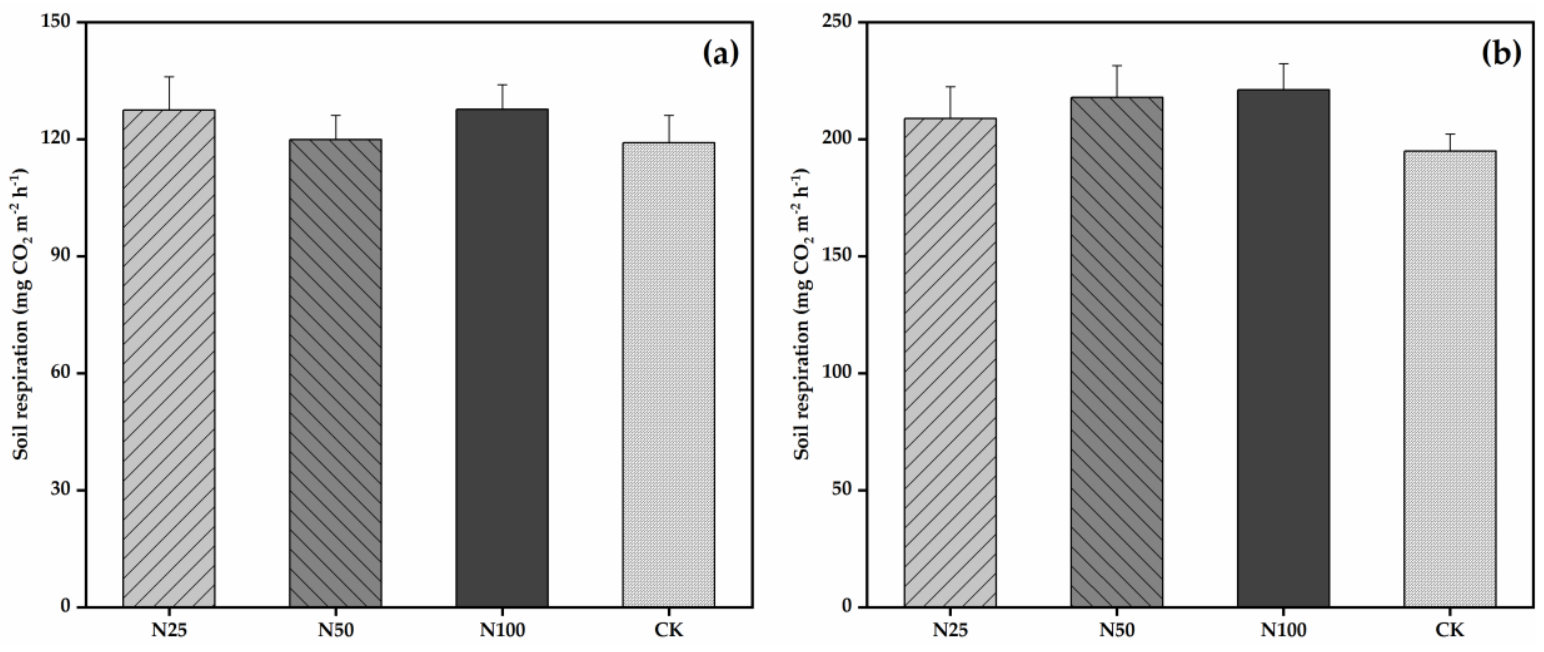

Figure 3. Mean $R_{S}$ under different $\mathrm{N}$ treatments in the dry season (a) and wet season (b). N25, N50, N100, and CK represent $25,50,100$, and $0 \mathrm{~kg} \mathrm{~N} \mathrm{ha}^{-1} \mathrm{a}^{-1} \mathrm{~N}$ addition treatments, respectively. Error bars denote the standard errors of the means. No significant variations were found among the four $\mathrm{N}$ treatments by one-way ANOVA regardless of season.

Table 3. Parameters of different regression models between $R_{\mathrm{S}}$, soil temperature $(\mathrm{T})$, and soil moisture (W).

\begin{tabular}{cccccccccc}
\hline & \multicolumn{4}{c}{$\boldsymbol{R}_{\mathbf{S}}=\mathbf{m} \times \mathbf{e}^{\mathbf{n T}}$} \\
\cline { 2 - 10 } & $\mathbf{m}$ & $\mathbf{n}$ & $\boldsymbol{R}^{\mathbf{2}}$ & $\boldsymbol{p}$ & $\boldsymbol{Q}_{\mathbf{1 0}}$ & $\mathbf{a}$ & $\mathbf{b}$ & $\boldsymbol{R}^{\mathbf{2}}$ & $\boldsymbol{p}$ \\
\hline N25 & 13.11 & 0.1237 & 0.50 & $<0.001$ & 3.45 & 5.32 & 27.83 & 0.35 & $<0.005$ \\
N50 & 9.36 & 0.1413 & 0.64 & $<0.001$ & 4.11 & 8.31 & -50.06 & 0.51 & $<0.001$ \\
N100 & 19.02 & 0.1078 & 0.52 & $<0.001$ & 2.94 & 5.96 & 31.01 & 0.27 & $<0.005$ \\
CK & 29.47 & 0.0821 & 0.41 & $<0.001$ & 2.27 & 7.03 & -35.37 & 0.46 & $<0.001$ \\
\hline
\end{tabular}

$\mathrm{m}, \mathrm{n}, \mathrm{a}$, and $\mathrm{b}$ are the model coefficients. The $Q_{10}$ value is obtained from $\mathrm{n}\left(Q_{10}=\mathrm{e}^{10 \mathrm{n}}\right) . \mathrm{N} 25, \mathrm{~N} 50, \mathrm{~N} 100$, and CK represent $25,50,100$, and $0 \mathrm{~kg} \mathrm{~N}$ ha $^{-1} \mathrm{a}^{-1} \mathrm{~N}$ addition treatments, respectively. 

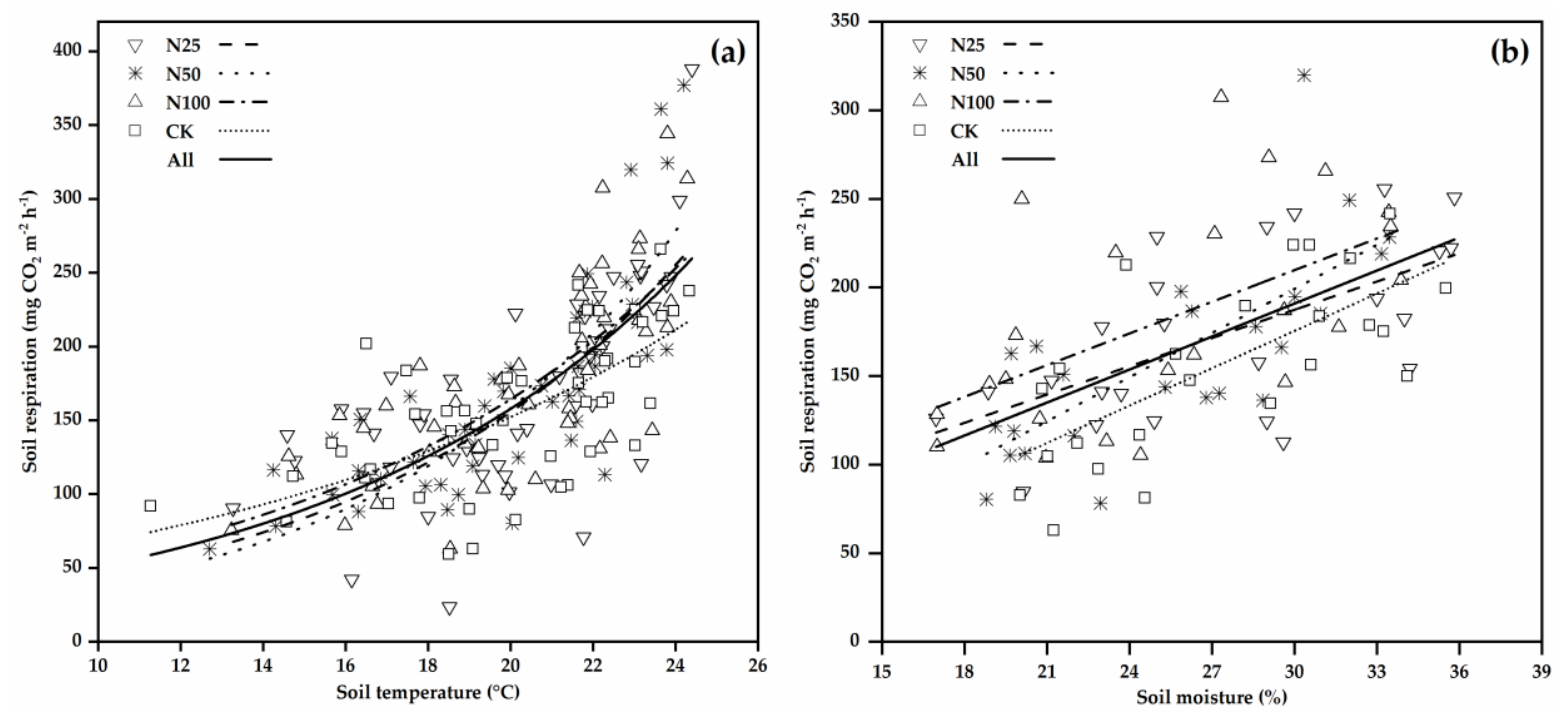

Figure 4. Relationships between $R_{\mathrm{S}}$ and soil temperature (a) and soil moisture (b) under different $\mathrm{N}$ treatments. Each data point represents the mean of three technical replicates. N25, N50, N100, and CK represent 25, 50, 100, and $0 \mathrm{~kg} \mathrm{~N} \mathrm{ha}^{-1} \mathrm{a}^{-1}$ $\mathrm{N}$ addition treatments, respectively.

\section{Discussion}

\subsection{Comparison with Previous Studies}

In this rainforest, the four-year average $R_{\mathrm{S}}$ measured in the $\mathrm{CK}$ plots was $156.97 \mathrm{mg} \mathrm{CO}_{2} \mathrm{~m}^{-2} \mathrm{~h}^{-1}$, which was comparable to previous studies in nearby forests (179.6 $\mathrm{mg} \mathrm{CO}_{2} \mathrm{~m}^{-2} \mathrm{~h}^{-1}$ ) [40] as well as a mixed forest in subtropical China (169.73 $\mathrm{mg} \mathrm{CO}_{2} \mathrm{~m}^{-2} \mathrm{~h}^{-1}$ ) [18]. The $R_{\mathrm{S}}$ value was lower than those reported in a mature tropical forest in China ( $\left.253 \mathrm{mg} \mathrm{CO} \mathrm{CO}^{-2} \mathrm{~h}^{-1}\right)$ [27] and a tropical rainforest in Indonesia (562.2 $\mathrm{mg} \mathrm{CO}_{2} \mathrm{~m}^{-2} \mathrm{~h}^{-1}$ ) [41].

The $Q_{10}$ in the CK treatment was 2.27 during the monitoring period, which was paralleled with that observed by Bekku et al. [42] for a secondary tropical forest in Malaysia $\left(Q_{10}=2.1\right)$, and by Mo et al. [20] for a disturbed tropical moist forest $\left(Q_{10}=2.3\right)$. However, the $Q_{10}$ value of the tropical montane rainforest in Jianfengling was lower than that reported in several temperate and subtropical forests in China [7,43,44], and slightly lower than the average $Q_{10}$ value of 2.51 estimated for China's forests [45]. Compared with other forest types, tropical forests are characterized by an abundant supply of soil organic matter (SOM), more complex species composition, and higher microbial biomass and enzyme activities; thus, a lower $Q_{10}$ value is expected $[46,47]$.

\subsection{Environmental Controls on Soil Respiration}

Previous research has demonstrated that soil temperature and moisture are two major factors regulating $R_{\mathrm{S}}[18,27]$. Our field data demonstrated that $R_{\mathrm{S}}$ positively correlated with soil temperature (Figure 4a). Indeed, soil temperature can affect substrate availability by adjusting seasonal $C$ distributions and daily metabolism, and can affect extracellular enzyme activities, which dominate soil microbial respiration [48-50]. Compared with the impact of temperature on $R_{\mathrm{S}}$, the impact of soil moisture on $R_{\mathrm{S}}$ is more complex. Soil moisture affects not only the physiological processes and activities of enzymes, but also gas diffusion [51,52]. It is generally believed that insufficient or excessive soil moisture will inhibit $R_{\mathrm{S}}$, but moderate soil moisture can stimulate $R_{\mathrm{S}}$. Our study field is situated in a humid tropical monsoon climate region with distinct dry and wet seasons, meaning soil moisture may have a crucial role in the seasonal patterns of $R_{\mathrm{S}}$.

Recent research has shown that the synergistic effect of soil moisture and temperature can better explain the changes in $R_{\mathrm{S}}$ over time relative to the influence of a single factor $[14,27]$. In our field experiment, low to negligible $R_{\mathrm{S}}$ was measured during the dry season when soil moisture and temperature were both low. Similarly, moderate to high $R_{\mathrm{S}}$ 
was measured during the wet season when soil moisture and temperature were both high (Figure 1). In addition, because no significant variations in soil moisture and temperature were found between the treatments (Table 1), we posited that soil moisture and temperature might not be the main reasons for the increase in $R_{S}$ observed in the different $N$ added treatments in our study.

\subsection{Effects of $N$ Additions on Soil Respiration}

Our findings imply that $\mathrm{N}$ addition has the potential to stimulate $R_{\mathrm{S}}$ in tropical forests, which agrees with other studies from tropical forests [15], a subtropical forest [53], and a temperate forest [19]. However, some previous research has indicated that $R_{\mathrm{S}}$ could be inhibited by $\mathrm{N}$ additions [54,55]. These contradicting results may stem from differences in the soil properties and ecosystem types [19]. $R_{\mathrm{S}}$ consists of both autotrophic (root) and heterotrophic (fungal and microbial) respiration [56], which is closely related with the amount of litter biomass and fine root biomass, and the microbial community size in soil [53,55]. In earlier studies conducted at our same site, Zhou [34] found that fine root biomass increased with an increase in $\mathrm{N}$ addition (when compared with the $\mathrm{CK}$, the fine root biomass in the N25, N50, and N100 treatments were 19\%, 27\%, and 36\% higher, respectively), which has been reported to have a positive impact on root respiration and rhizosphere respiration [16,24]. Moreover, experimental $\mathrm{N}$ addition has been reported to increase soil organic carbon (SOC) at the study site [34], which provides more substrate for the microbial community and enzyme activity, and then increases microbial biomass and microbial respiration [57,58]. Similarly, Cleveland and Townsend [15] found that after experimental $\mathrm{N}$ addition, higher $R_{\mathrm{S}}$ of a tropical forest could arise from greater root respiration, more rapid decomposition by the microbial community, or both. These positive impacts eventually contribute to the promotion of $R_{\mathrm{S}}$ by $\mathrm{N}$ addition.

It should be noted that there was no significant variation in $R_{\mathrm{S}}$ across treatments (Table 2; Figure 2). A reason for this might be that $\mathrm{N}$ additions did not alter SOC and fine root biomass significantly at our site [34], that is, $\mathrm{N}$ additions did not remarkably change the specific respiration rates of microbes and fine roots, and thus $\mathrm{N}$ additions had no significant impact on $R_{S}$. At the same experimental field, Tang et al. [26] found that most soil characteristics (soil $\mathrm{pH}$, dissolved organic carbon, total $\mathrm{N}$, etc.) were not significantly different under different $\mathrm{N}$ treatments at different seasonal stages. This may be one of the reasons for the insignificant variation in $R_{\mathrm{S}}$ between different $\mathrm{N}$ additions in neither the wet season nor the dry season (Figure 3). As we did not measure some related parameters, the underlying mechanistic connection between $\mathrm{N}$ additions and $R_{\mathrm{S}}$ is still not clear.

\subsection{Effects of $N$ Additions on Temperature Sensitivity}

$Q_{10}$ values reflect the response intensity of $R_{S}$ to rising temperatures, which is one of the key ecological parameters in ecosystem $\mathrm{C}$ cycle models [59]. While $\mathrm{N}$ addition has been widely indicated to decrease the $Q_{10}$ value $[7,13,53]$, our results demonstrated that $\mathrm{N}$ additions can increase $Q_{10}$ values for the entire study period (Table 3 ), which agrees with previous observations [24,60]. The increase in $Q_{10}$ in our study indicates that $N$ addition may, in fact, strengthen the temperature control on $R_{\mathrm{S}}$ at our study site. On one hand, $\mathrm{N}$ addition can promote the growth of vegetation, increase the respiratory substrate supply (e.g., SOC), and thus increase the $Q_{10}$ value [24]. On the other hand, $N$ addition can stimulate the enzyme activity related to the decomposition of SOM [61], thereby promoting the decomposition of SOM that leads to an increase in the $Q_{10}$ values.

Additionally, the response magnitudes of $Q_{10}$ to different $N$ treatment levels may be different in different forest types. For example, at our site, the highest $Q_{10}$ value appeared in the N50 treatment and the lowest appeared in the N100 treatment (Table 3). In contrast, Tu et al. [13] discovered that the highest value of $Q_{10}$ in a subtropical forest appeared in the low-N plots and the lowest appeared in the high-N plots. The variations of the $Q_{10}$ value with different levels of $\mathrm{N}$ additions reflect the change in enzyme activity, microbial composition, and/or metabolic pathways in the soils $[13,23,58]$. However, the impact of $\mathrm{N}$ 
addition on the $Q_{10}$ is a complex dynamic, and the specific elaborations for the responses of $Q_{10}$ to different quantities of $\mathrm{N}$ additions in various ecosystems remain unclear and warrant further study.

\subsection{Uncertainties and Limitations}

There are some uncertainties and limitations in this study. The static chamber-gas chromatography method was used to measure $\mathrm{CO}_{2}$ flux $\left(R_{\mathrm{S}}\right)$ between the soil and the atmosphere. As reported previously, the quality of the measured flux is affected by many factors, including the methodology, physical and biological disturbances, instrument performance, and the storage and transportation of gas samples [62-64]. At our site, the uncertainty of the static chamber measurements may result from the estimation, because all measured $\mathrm{CO}_{2}$ fluxes, used to represent the daily and even monthly $R_{\mathrm{S}}$, were implemented during the daytime. Additionally, continuous measurement of $R_{\mathrm{S}}$ at one location with a chamber may change the soil moisture and temperature in the chamber [64], which can add some uncertainties into the $R_{\mathrm{S}}$ evaluations. For example, Janssens et al. [65] found that when the temperature and moisture in the air and soil within the chamber change, both soil decomposition and root respiration rates will be affected, resulting in changes in $R_{\mathrm{S}}$.

Litter decomposition rate, fine root biomass, and soil microbial activity are important parameters to our understanding of the effects of $\mathrm{N}$ additions on $R_{\mathrm{S}}[16,66]$, none of which were measured in the present study. More auxiliary data could help us comprehend the mechanisms of the impact of $\mathrm{N}$ addition on $R_{\mathrm{S}}$ and its $Q_{10}$. An improved understanding of the responses of $R_{\mathrm{S}}$ and its $Q_{10}$ to increasing $\mathrm{N}$ deposition in tropical forests will enable us to reduce the uncertainty regarding $R_{\mathrm{S}}$ estimations. Therefore, more detailed investigations on the impacts of $\mathrm{N}$ additions on $R_{\mathrm{S}}$ and its $Q_{10}$ are critically needed in tropical forests.

\section{Conclusions}

We measured $R_{\mathrm{S}}$ in an undisturbed tropical montane rainforest within the JFLNNR, China from 2015 to 2018 after different levels of $\mathrm{N}$ additions. Our results showed that the seasonal dynamics of $R_{\mathrm{S}}$ subject to $\mathrm{N}$ additions were similar to the control condition. $\mathrm{N}$ additions had no significant effects on $R_{\mathrm{S}}$, but the increase in $\mathrm{N}$ availability can promote the $R_{\mathrm{S}}$ to a certain extent. We inferred the possible mechanism driving the increase of $R_{\mathrm{S}}$ was an increase in the SOC and fine root biomass related to $\mathrm{N}$ additions. Our analysis showed that $\mathrm{N}$ additions also increased $Q_{10}$ during the whole study period, but this varied with different $\mathrm{N}$ addition levels. More comprehensive studies should be conducted to better comprehend how rates of $\mathrm{N}$ addition affect $Q_{10}$ in this system. In summary, both $R_{\mathrm{S}}$ and its $Q_{10}$ increased with added $\mathrm{N}$, suggesting that the large soil $\mathrm{C}$ stocks contained in tropical rainforest soils are likely to be highly vulnerable to ongoing global change and current and projected rates of $\mathrm{N}$ deposition.

Author Contributions: Conception and design of the paper: C.P. and W.L.; data collection: F.W., D.C., and Y.L.; data processing: F.W., Z.L., and H.W.; drafting the paper: F.W. and C.P. All authors have read and agreed to the published version of the manuscript.

Funding: This study was supported by the National Key R\&D Program of China (2016YFC0500203) and a Natural Sciences and Engineering Research Council of Canada Discovery Grant.

Data Availability Statement: The data presented in this study are available from the corresponding author on reasonable request.

Conflicts of Interest: The authors declare no conflict of interest.

\section{References}

1. IPCC. Climate Change 2013: The Physical Science Basis. Contribution of Working Group I to the Fifth Assessment Report of the Intergovernmental Panel on Climate Change; Cambridge University Press: Cambridge, UK, 2013.

2. Chaturvedi, A. Will Carbon Market Change the Fate of This Planet? Available online: https://ssrn.com/abstract=3632416; http:/ / dx.doi.org/10.2139/ssrn.3632416 (accessed on 4 March 2021). 
3. Huntzinger, D.; Michalak, A.; Schwalm, C.; Ciais, P.; King, A.; Fang, Y.; Schaefer, K.; Wei, Y.; Cook, R.; Fisher, J.; et al. Uncertainty in the response of terrestrial carbon sink to environmental drivers undermines carbon-climate feedback predictions. Sci. Rep. 2017, 7, 4765. [CrossRef] [PubMed]

4. Trumper, K.; Bertzky, M.; Dickson, B.; van der Heijden, G.; Jenkins, M.; Manning, P. The Natural Fix? The Role of Ecosystems in Climate Mitigation; A UNEP Rapid Response Assessment; United Nations Environment Programme, UNEP-WCMC: Cambridge, UK, 2009.

5. Xu, M.; Shang, H. Contribution of soil respiration to the global carbon equation. J. Plant Physiol. 2016, 203, 16-28. [CrossRef]

6. Bowden, R.; Davidson, E.; Savage, K.; Arabia, C.; Steudler, P. Chronic nitrogen additions reduce total soil respiration and microbial respiration in temperate forest soils at the Harvard Forest. Forest Ecol. Manag. 2004, 196, 43-56. [CrossRef]

7. Sun, Z.; Liu, L.; Ma, Y.; Yin, G.; Zhao, C.; Zhang, Y.; Piao, S. The effect of nitrogen addition on soil respiration from a nitrogenlimited forest soil. Agric. For. Meteorol. 2014, 197, 103-110. [CrossRef]

8. Scott-Denton, L.; Sparks, K.; Monson, R. Spatial and temporal controls over soil respiration rate in a high-elevation, subalpine forest. Soil Biol. Biochem. 2003, 35, 525-534. [CrossRef]

9. Monson, R.; Lipson, D.; Burns, S.; Turnipseed, A.; Delany, A.; Williams, M.; Schmidt, S. Winter forest soil respiration controlled by climate and microbial community composition. Nature 2006, 439, 711-714. [CrossRef] [PubMed]

10. Prasad, S.; Baishya, R. Interactive effects of soil moisture and temperature on soil respiration under native and non-native tree species in semi-arid forest of Delhi, India. Trop. Ecol. 2019, 60, 252-260. [CrossRef]

11. Čater, M.; Darenova, E.; Simončič, P. Harvesting intensity and tree species affect soil respiration in uneven-aged Dinaric forest stands. Forest Ecol. Manag. 2021, 480, 118638. [CrossRef]

12. Vitousek, P.; Howarth, R. Nitrogen limitation on land and in the sea: How can it occur? Biogeochemistry 1991, 13, 87-115. [CrossRef]

13. Tu, L.; Hu, T.; Zhang, J.; Li, X.; Hu, H.; Liu, L.; Xiao, Y. Nitrogen addition stimulates different components of soil respiration in a subtropical bamboo ecosystem. Soil Biol. Biochem. 2013, 58, 255-264. [CrossRef]

14. Zhou, S.; Xiang, Y.; Tie, L.; Han, B.; Huang, C. Simulated nitrogen deposition significantly reduces soil respiration in an evergreen broadleaf forest in western China. PLoS ONE 2018, 13, e0204661. [CrossRef] [PubMed]

15. Cleveland, C.; Townsend, A. Nutrient additions to a tropical rain forest drive substantial soil carbon dioxide losses to the atmosphere. Proc. Natl. Acad. Sci. USA 2006, 103, 10316-10321. [CrossRef] [PubMed]

16. Gao, Q.; Hasselquist, N.; Palmroth, S.; Zheng, Z.; You, W. Short-term response of soil respiration to nitrogen fertilization in a subtropical evergreen forest. Soil Biol. Biochem. 2014, 76, 297-300. [CrossRef]

17. Ambus, P.; Robertson, G. The effect of increased N deposition of nitrous oxide, methane and carbon dioxide fluxes from unmanaged forest and grassland communities in Michigan. Biogeochemistry 2006, 79, 315-337. [CrossRef]

18. Gao, W.; Yang, H.; Li, S.; Kou, L. Responses of soil $\mathrm{CO}_{2}, \mathrm{CH}_{4}$ and $\mathrm{N}_{2} \mathrm{O}$ fluxes to $\mathrm{N}$, $\mathrm{P}$, and acid additions in mixed forest in subtropical China. J. Resour. Ecol. 2017, 8, 154-164.

19. Wang, C.; Yang, X.; Xu, K. Effect of chronic nitrogen fertilization on soil $\mathrm{CO}_{2}$ flux in a temperate forest in North China: A 5-year nitrogen addition experiment. J. Soil Sed. 2018, 18, 506-516. [CrossRef]

20. Mo, J.; Zhang, W.; Zhu, W.; Fang, Y.; Li, D.; Zhao, P. Response of soil respiration to simulated N deposition in a disturbed and a rehabilitated tropical forest in southern China. Plant Soil 2007, 296, 125-135. [CrossRef]

21. Lü, C.; Tian, H. Spatial and temporal patterns of nitrogen deposition in China: Synthesis of observational data. J. Geophys. Res. 2007, 112, D22S05. [CrossRef]

22. Du, Y.; Guo, P.; Liu, J.; Wang, C.; Yang, N.; Jiao, Z. Different types of nitrogen deposition show variable effects on the soil carbon cycle process of temperate forests. Glob. Chang. Biol. 2014, 20, 3222-3228. [CrossRef]

23. Liu, B.; Mou, C.; Yan, G.; Xu, L.; Jiang, S.; Xing, Y.; Han, S.; Yu, J.; Wang, Q. Annual soil $\mathrm{CO}_{2}$ efflux in a cold temperate forest in northeastern China: Effects of winter snowpack and artificial nitrogen deposition. Sci. Rep. 2016, 6, 18957. [CrossRef] [PubMed]

24. Deng, Q.; Zhou, G.; Liu, J.; Liu, S.; Duan, H.; Zhang, D. Responses of soil respiration to elevated carbon dioxide and nitrogen addition in young subtropical forest ecosystems in China. Biogeosciences 2010, 7, 315-328. [CrossRef]

25. Peng, Y.; Song, S.; Li, Z.; Li, S.; Chen, G.; Hu, H.; Xie, J.; Chen, G.; Xiao, Y.; Liu, L.; et al. Influences of nitrogen addition and aboveground litter-input manipulations on soil respiration and biochemical properties in a subtropical forest. Soil Biol. Biochem. 2020, 142, 107694. [CrossRef]

26. Tang, W.; Chen, D.; Phillips, O.; Liu, X.; Zhou, Z.; Li, Y.; Xi, D.; Zhu, F.; Fang, J.; Zhang, L.; et al. Effects of long-term increased N deposition on tropical montane forest soil $\mathrm{N}_{2}$ and $\mathrm{N}_{2} \mathrm{O}$ emissions. Soil Biol. Biochem. 2018, 126, 194-203. [CrossRef]

27. Mo, J.; Zhang, W.; Zhu, W.; Gundersen, P.; Fang, Y.; Li, D.; Wang, H. Nitrogen addition reduces soil respiration in a mature tropical forest in southern China. Glob. Chang. Biol. 2008, 14, 403-412. [CrossRef]

28. Du, E.; Terrer, C.; Pellegrini, A.; Ahlström, A.; van Lissa, C.; Zhao, X.; Xia, N.; Wu, X.; Jackson, R. Global patterns of terrestrial nitrogen and phosphorus limitation. Nat. Geosci. 2020, 13, 221-226. [CrossRef]

29. Du, E.; Zhou, Z.; Li, P.; Hu, X.; Ma, Y.; Wang, W.; Zheng, C.; Zhu, J.; He, J.; Fang, J. NEECF: A project of nutrient enrichment experiments in China's forests. J. Plant Ecol. 2013, 6, 428-435. [CrossRef]

30. Wang, A.; Zhu, W.; Gundersen, P.; Phillips, O.; Chen, D.; Fang, Y. Fates of atmospheric deposited nitrogen in an Asian tropical primary forest. For. Ecol. Manag. 2018, 411, 213-222. [CrossRef]

31. Chen, D.; Li, Y.; Liu, H.; Xu, H.; Xiao, W.; Luo, T.; Zhou, Z.; Lin, M. Biomass and carbon dynamics of a tropical mountain rain forest in China. Sci. China Life Sci. 2010, 53, 798-810. [CrossRef] 
32. Fang, J.; Li, Y.; Zhu, B.; Liu, G.; Zhou, G. Community structures and species richness in the montane rain forest of Jianfengling, Hainan Island, China. Biodivers. Sci. 2004, 12, $29-43$.

33. Shi, J.; Xu, H.; Lin, M.; Li, Y. Dynamics of litterfall production in the tropical mountain rainforest of Jianfengling, Hainan Island, China. Plant Sci. J. 2019, 37, 593-601.

34. Zhou, Z. Effects of Nitrogen and Phosphorus Additions on Carbon Cycling of Tropical Mountain Rainforests in Hainan Island, China. Ph.D. Thesis, Peking University, Beijing, China, June 2013.

35. Bai, Z.; Yang, G.; Chen, H.; Zhu, Q.; Chen, D.; Li, Y.; Wang, X.; Wu, Z.; Zhou, G.; Peng, C. Nitrous oxide fluxes from three forest types of the tropical mountain rainforests on Hainan Island, China. Atmos. Environ. 2014, 92, 469-477. [CrossRef]

36. Hutchinson, G.; Mosier, A. Improved soil cover method for field measurement of nitrous oxide fluxes. Soil Sci. Soc. Am. J. 1981, 45, 311-316. [CrossRef]

37. Chen, Z.; Ding, W.; Luo, Y.; Yu, H.; Xu, Y.; Müller, C.; Xu, X.; Zhu, T. Nitrous oxide emissions from cultivated blacksoil: A case study in Northeast China and global estimates using empirical model. Glob. Biogeochem. Cycles 2014, 27, 1311-1326. [CrossRef]

38. Badalucco, L.; Gelsomino, A.; Dellorco, S.; Grego, S.; Nannipieri, P. Biochemical characterization of soil organic compounds extracted by $0.5 \mathrm{M} \mathrm{K}_{2} \mathrm{SO}_{4}$ before and after chloroform fumigation. Soil Biol. Beachem. 1992, 24, 569-578. [CrossRef]

39. Lloyd, J.; Taylor, J. On the temperature dependence of soil respiration. Funct. Ecol. 1994, 8, 315-323. [CrossRef]

40. Wei, H. Soil Greenhouse Gas Emission and Its Influencing Factors from Temperate Deciduous Broad-leaved Forest and Tropical Mountain Rain Forest. Ph.D. Thesis, Northwest A\&F University, Yangling, China, September 2018.

41. Ishizuka, S.; Iswandi, A.; Nakajima, Y.; Yonemura, S.; Sudo, S.; Tsuruta, H.; Muriyarso, D. Spatial patterns of greenhouse gas emission in a tropical rainforest in Indonesia. Nutr. Cycl. Agroecosyst. 2005, 71, 55-62. [CrossRef]

42. Bekku, Y.; Nakatsubo, T.; Kume, A.; Adachi, M.; Koizumi, H. Effect of warming on the temperature dependence of soil respiration rate in arctic, temperate and tropical soils. Appl. Soil Ecol. 2003, 22, 205-210. [CrossRef]

43. Wang, C.; Yang, J.; Zhang, Q. Soil respiration in six temperate forests in China. Glob. Chang. Biol. 2006, 12, 2103-2114. [CrossRef]

44. Yuan, C.; Zhu, G.; Yang, S.; Xu, G.; Li, Y.; Gong, H.; Wu, C. Soil warming increases soil temperature sensitivity in subtropical Forests of SW China. PeerJ 2019, 7, e7721. [CrossRef]

45. Xu, Z.; Tang, S.; Xiong, L.; Yang, W.; Yin, H.; Tu, L.; Wu, F.; Chen, L.; Tan, B. Temperature sensitivity of soil respiration in China's forest ecosystems: Patterns and controls. Appl. Soil Ecol. 2015, 93, 105-110. [CrossRef]

46. Jiang, L.; Ma, S.; Zhou, Z.; Zheng, T.; Jiang, X.; Cai, Q.; Li, P.; Zhu, J.; Li, Y.; Fang, J. Soil respiration and its partitioning in different components in tropical primary and secondary mountain rain forests in Hainan Island, China. J. Plant Ecol. 2017, 10, 791-799. [CrossRef]

47. Zimmermann, M.; Davies, K.; Peña de Zimmermann, V.; Bird, M. Impact of temperature and moisture on heterotrophic soil respiration along a moist tropical forest gradient in Australia. Soil Res. 2015, 53, 286-297. [CrossRef]

48. Campbell, J.; Law, B. Forest soil respiration across three climatically distinct chronosequences in Oregon. Biogeochemistry 2005, 73, 109-125. [CrossRef]

49. Ryan, M.; Law, B. Interpreting, measuring, and modeling soil respiration. Biogeochemistry 2005, 73, 3-27. [CrossRef]

50. Kittredge, H.; Cannone, T.; Funk, J.; Chapman, S. Soil respiration and extracellular enzyme production respond differently across seasons to elevated temperatures. Plant Soil 2018, 425, 351-361. [CrossRef]

51. Ilsteld, U.; Nordgren, A.; Malmer, M. Optimum soil water for soil respiration before and after amendment with glucose in humid tropical acrisols and a boreal mor layer. Soil Biol. Biochem. 2000, 32, 1591-1599.

52. Phillips, C.; Nickerson, N.; Risk, D.; Kayler, Z.; Andersen, C.; Mix, A.; Bond, B. Soil moisture effects on the carbon isotope composition of soil respiration. Rapid Commun. Mass Spectrom. 2010, 24, 1271-1280. [CrossRef] [PubMed]

53. Li, Q.; Song, X.; Chang, S.; Peng, C.; Xiao, W.; Zhang, J.; Xiang, W.; Li, Y.; Wang, W. Nitrogen depositions increase soil respiration and decrease temperature sensitivity in a Moso bamboo forest. Agric. For. Meteorol. 2019, 268, 48-54. [CrossRef]

54. Wang, Q.; Zhang, W.; Sun, T.; Chen, L.; Pang, X.; Wang, Y.; Xiao, F. N and P fertilization reduced soil autotrophic and heterotrophic respiration in a young Cunninghamia lanceolata forest. Agric. For. Meteorol. 2017, 232, 66-73. [CrossRef]

55. Yan, W.; Chen, X.; Peng, Y.; Zhu, F.; Zhen, W.; Zhang, X. Response of soil respiration to nitrogen addition in two subtropical forest types. Pedosphere 2020, 30, 478-486. [CrossRef]

56. Sotta, E.; Meir, P.; Malhi, Y.; Nobre, A.; Hodnett, M.; Grace, J. Soil $\mathrm{CO}_{2}$ efflux in a tropical forest in the central Amazon. Glob. Chang. Biol. 2004, 10, 601-617. [CrossRef]

57. Song, L.; Tian, P.; Zhang, J.; Jin, G. Effects of three years of simulated nitrogen deposition on soil nitrogen dynamics and greenhouse gas emissions in a Korean pine plantation of northeast China. Sci. Total Environ. 2017, 609, 1303-1311. [CrossRef]

58. Xiao, H.; Shi, Z.; Li, Z.; Wang, L.; Chen, J.; Wang, J. Responses of soil respiration and its temperature sensitivity to nitrogen addition: A meta-analysis in China. Appl. Soil Ecol. 2020, 150, 103484. [CrossRef]

59. Zhou, T.; Shi, P.; Hui, D.; Luo, Y. Global pattern of temperature sensitivity of soil heterotrophic respiration $\left(Q_{10}\right)$ and its implications for carbon-climate feedback. J. Geophys. Res. 2009, 114, G02016. [CrossRef]

60. Cusack, D.; Torn, M.; McDowell, W.; Silver, W. The response of heterotrophic activity and carbon cycling to nitrogen additions and warming in two tropical soils. Glob. Chang. Biol. 2010, 16, 2555-2572. [CrossRef]

61. Sinsabaugh, R.; Gallo, M.; Lauber, C.; Waldrop, M.; Zak, D. Extracellular enzyme activities and soil organic matter dynamics for northern hardwood forests receiving simulated nitrogen deposition. Biogeochemistry 2005, 75, 201-215. [CrossRef]

62. Fang, C.; Moncrieff, J. An open-top chamber for measuring soil respiration and the influence of pressure difference on $\mathrm{CO}_{2}$ efflux measurement. Funct. Ecol. 1998, 12, 319-325. [CrossRef] 
63. Davidson, E.; Savage, K.; Verchot, L.; Navarro, R. Minimizing artifacts and biases in chamber-based measurements of soil respiration. Agric. For. Meteorol. 2002, 113, 21-37. [CrossRef]

64. Liang, N.; Nakadai, T.; Hirano, T.; Qu, L.; Koike, T.; Fujinuma, Y.; Inoue, G. In situ comparison of four approaches to estimating soil $\mathrm{CO}_{2}$ efflux in a northern larch (Larix kaempferi Sarg.) forest. Agric. For. Meteorol. 2004, 123, 97-117. [CrossRef]

65. Janssens, I.; Kowalski, A.; Longdoz, B.; Ceulemans, R. Assessing forest soil $\mathrm{CO}_{2}$ efflux: An in-situ comparison of four techniques. Tree Physiol. 2000, 20, 23-32. [CrossRef]

66. Zheng, S.; Bian, H.; Quan, Q.; Xu, L.; Chen, Z.; He, N. Effect of nitrogen and acid deposition on soil respiration in a temperate forest in China. Geoderma 2018, 329, 82-90. [CrossRef] 